\title{
THE SWISS CITY CANTON: A POLITICAL INVENTION*
}

All major Swiss cities are located north of the Alps. Their development can be understood best as part of the development of the North European cities - those of Germany, Flanders and France - and as part of the communal movement as it developed in those areas. Yet the cities that eventually became Swiss are those that accepted more of the characteristic institutions of Italian city-states than did the rest, and it is this acceptance of certain Italian practices - particularly the creation of a rural territory and thus eventually of a territorial city-state - that made those cities into city Cantons, able to take part in the formation of Switzerland.

This paper will first of all describe the main alternative developments of the economic and political interests of cities, and the most relevant features of the cities of Northern Europe. It will then show in what respects the developing Swiss city Cantons resembled either the North European or the Italian models, and to what extent their development was characterized by original Swiss political inventions.

\section{SOME POSSIBLE CONFIGURATIONS OF THE INTERESTS OF CITIES}

In the short run, practical politicians as well as students of politics tend to consider political and economic interests as given. Politics then appears as the more or less effective expression or pursuit of these interests that have already been determined. A more long-range analysis, however, must consider the alternative ways in which interests may be not only perceived and pursued, but also weakened or strengthened, aggregated and developed in alternative patterns by political action. If interests go far in making politics, political decisions, in turn, go far to change and remake interests and interest configurations. As in the proverbial case of the chicken and the egg, the processes of evolution and selection may operate at either or both stages of the cycle.

The basic interests of medieval cities, and of the elites ruling them, may be

* Adapted from a chapter of a forthcoming book, United for Diversity: The Political Integration of the Swiss People, by Karl W. Deutsch and Hermann Weilenmann, based on research supported by the Carnegie Corporation. 
grouped under sixteen headings, as shown schematically in the Table that follows. The first eight of these are economic, in four groupings, relating to trade, craft, creditor and employer interests, respectively. The remaining eight interests are social and political. These may be put under three groups, pertaining to status, political autonomy, and social and political integration.

\section{TABLE}

Some Major Interests and Interest Configurations in 14th-16th Century Europe

Interests

Groups Affected *

(1) (2) (3) (4)

Urban Urban Peas- Rural

(5) (6)

Elites Poor ants Nobles Churches Princes

I. Economic

A. Trade

1. Open trade routes

2. Monopolistic advantages

B. Crafts

3. Cheap food imports

4. Monopolistic advantages against peasants

C. Credit

5. Privileged lending to nobles and/or peasants

6. Enforcement of collections

D. Employer

7. Cheap non-competitive labor

8. Subordination of urban poor

$\begin{array}{llllll}+ & + & + & - & + & + \\ + & + & - & - & - & +\end{array}$

$\begin{array}{llllll}+ & + & - & - & + & + \\ + & + & - & - & - & +\end{array}$

II. Social \& Political

E. Status

9. Equal status vs. nobles

10. Superior status vs. peasants

11. Superior status vs. urban poor

F. Political Autonomy

12. Internal

13. External

G. Integration (including poor)

14. Civic Solidarity

15. Civic Participation

16. Integration with countryside

Total number of favorable interests 16

with urban elites

$\begin{array}{llllll}+ & + & + & - & - & - \\ + & + & - & + & + & + \\ + & + & + & + & + & +\end{array}$

* + favorably, - unfavorably.

Note: This tabulation is grossly simplified. Most obviously it disregards the relative weight of the interests listed. In some cities, the four interests shared by the urban rich with the rural nobles might outweigh the twelve interests - less salient to them which they might share with the urban poor. It has also to be remembered that political victories or representation of artisan crafts, though reducing the power of the merchant 
The trade interests of a city involve the keeping open of trade routes and trade opportunities, and in the second place, the acquisition of monopolistic advantages in both buying and selling, resulting in favorable terms of trade vis-à-vis the city's customers and sources of supply. The craft interests were somewhat similar: they consisted in winning and maintaining monopolistic advantages in regard to all craft products and services, as against all possible competitors and customers; in securing a cheap and dependable food supply; and thus in maintaining highly favorable terms of trade against the countryside - both peasants and nobles - who would have to exchange relatively cheap food for relatively expensive products of the urban craft monopolies.

Another urban economic interest was the creditor interest. This involved first of all the securing of the creditor role for the town burghers, and the elimination or restriction of other sources of credit, such as the Jews, or else their eventual incorporation into the body of citizens, as might happen in the case of the Lombards and Cahorsins. Beyond this, the urban creditor interest then called for protected - i.e., monopolistic - opportunities to lend money at interest to nobles, and possibly also directly to peasants; and it called particularly for dependable facilities for enforcing payments of these debts, including the seizure of pawns, the foreclosing of property, and the acquisition of feudal or peasant land by urban creditors.

Finally, there developed in the economically more advanced cities an employer interest. This interest on the part of the wealthier citizens and the urban elites grew up with the rise of wage labor and other economic practices foreshadowing the capitalism of later centuries. It included an interest in cheap sources of labor, and in the firm economic, social and political subordination of the urban poor.

Related to these various potential economic interests, but distinct from them, were the status interests of the urban populations, and particularly of the urban elites. On the one hand, the burghers wanted equality of status that is, of rights, of respect, attention, prestige, and access to offices and office-holders - vis-à-vis the aristocracy, outside the town or within it. On the other hand, the same burghers might - and not rarely did — want superior social status vis-à-vis the peasantry, and they also might want to be able to look down upon the urban poor and upon the more recent immigrants into the city - thus claiming at the same time equality against the nobles and oligarchy against the countryside and against many of their fellow townsmen.

Any and all of these diverse interests required for their pursuit political opportunities and political institutions, and thus gave rise to political interests

entrepreneurs who had at first ruled industrial cities, could not eliminate their influence where export industry was concerned nor prevent its reliance in some places on rural labor. See the chapters by A. B. Hibbert and by Sylvia L. Thrupp on "The Economic Policies of Towns" and "The Gilds" in The Cambridge Economic History of Europe, vol. III (Cambridge University Press, 1963). 
of the cities and their leaders. First among these was the interest in internal self-government for the city - in the fullest possible autonomy in regard to judicial, fiscal and internal political matters. Hardly second to this was the interest of most cities in being subject to little or no external taxation, in being able to buy external military or political protection cheaply, or in providing it for themselves at tolerable cost, in controlling their own external relations, and thus in winning and holding as much as possible of the substance and form of political sovereignty.

Last but not least in this list of potential urban interests was the interest of each city in some substantial degree of social and political integration. Where it existed, such integration would manifest itself in civic solidarity, in the readiness of all townsfolk to serve their city, to support it by taxes or labor, and to take active part in its defense against external enemies. Without such solidarity and broad civic military participation, even large cities were helpless before outside powers, or they became dependent upon mercenaries and their captains. The other side of this same coin of civic solidarity was civic, social and political participation, the leadership by broad and relatively open elites, with significant opportunities for social and economic rise of gifted and energetic persons from all strata. Together, these factors went far to determine the internal stability of cities and their governments, as well as their strength and their chances of preserving their independence against outside powers.

\section{THE CHOICE OF INTERESTS AND POLICIES}

In the preceding paragraphs we have listed sixteen interrelated but distinct potential economic, social and political interests of cities. In most cities whose political history is relevant for our discussion, most of these potential interests became actual, at least at some time and to some degree.

To pursue all these interests at once would have been quite impossible. In order to assert some of these interests against the rural nobles, the leaders of a city might need the backing of their own poorer townsfellows, or the backing of a powerful abbot, or bishop, or territorial prince, - or even an alliance with the peasantry. In order to exploit the countryside, conversely, a city had to have the backing of a prince, or at least the support of a large part of its own people. And in order to maintain or even increase the subordination of the poorer - and much larger - part of the city's own population, notably the wage earners such as the notoriously unruly journeymen, the elite members and would-be oligarchs of a city had to secure the tolerance for support of outside nobles, as well as often also of churchmen and of the overlord of the city, where there still was one, or of the territorial prince, for the preservation of their unpopular regime within the city.

In each case, choices had to be made. The choice of the interest to be put 
foremost at each stage might seem obvious and "naturally" given from the conditions then prevailing in the city. Once taken, however, the choice of most salient interests dictated to a significant degree the choice of policies, of allies, and of institutions. No less sharply it determined what policies and alliances had to be foregone. The results of all these choices, in their interplay with external events, in turn then strengthened or weakened or otherwise changed the interests and interest configurations from which the original policies had started; and the changed interests in turn once again pushed the policies and alliances of each city in some direction in which they once more would modify the city's interests.

The perception, pursuit and redefinition of the social, economic and political interests of a medieval city - much like all interest-based policies to this day - thus formed part of a repetitive feedback cycle. This feedback cycle might be negative in nature, that is, later developments might often counteract the earlier choices of leading interests and policies and thus, in the long run, keep the city on some middle course, with no one interest configuration becoming solidly dominant. Or the feedback cycle of interests and policies might be amplifying, that is, self-reinforcing, so that later policies would ever further strengthen the interests from which they had arisen, until a very sharply-defined and perhaps quite one-sided interest configuration would become dominant for a long time. By choosing its favored interests and policies, a city thus would choose, in part, its nature. The interests favored, and the long-term strategies chosen by either commission or omission, would often determine the type of cities, and the type that emerged as predominant would then determine the character of urban politics for a major period and region.

\section{FROM COMPETITION TO TYRANNY: THE POLITICAL STRATEGY OF THE ITALIAN CITY-STATES}

In great Italian cities such as Milan and Florence, policies were chosen that tended for a long time to promote all of the sixteen interests listed above, except the last three, relating to social integration - the interests of civic solidarity and voluntary popular political participation, both within the city and in relation to the countryside under its rule.

In the language of our Table, the governments of these great Italian communes first during the 11th and 12th centuries had followed mixed alliance policies of types 2,3 and 5 , that is, of alliances with the urban poor, the peasants and the Church. A modern historian comments on the mildness of social distinction and the ease of rise into the upper classes in the Italian communes of that time; and the victory of the Lombard communes over Emperor Barbarossa at Legnano in 1176 furnished impressive evidence of 
their civic solidarity. ${ }^{1}$ Attempts in the early 13 th century to subject church property to communal taxation, as in Cremona, Piacenza, Bergamo and Treviso, proved short-lived. ${ }^{2}$ From the mid-thirteenth century onward, however, the dominant policies of most of the Italian communes changed toward strategies of types 1 and 4, pursuing chiefly the interests of the urban mercantile and financial elites alone, but also including the nobles of the contado who had become included in the effective body politic of the city-state. The profits of these policies are still visible in the palaces and art treasures left to posterity by the elites of many Italian cities.

Some of the costs of these policies became visible already in the 12th and even more the 13th century. A Genoese law of 1159 barred the testimony of peasants in all lawsuits exceeding 100 soldi. The statutes of Parma in 1255 set the compensation for damage or injury done to a peasant at one-fifth (20 soldi) of the 100 soldi compensation established for the same damage done to an urban citizen. At Siena, the Constitution of 1262 set the penalties for offenses against peasants at one-half of those for the same offenses against citizens, if the offender also was a peasant; if he was a citizen, the penalties were further reduced to one-quarter of those for offenses against citizens. At Bologna, where the peasants had been made legally free in 1256 , the Statutes of 1282 ordained that, in case of disobedience of the peasants against the city, their villages were to be burned with everything in them, the trees cut down, and their lands confiscated. ${ }^{3}$

The subordination of the Italian peasants under the city-states and their elites became more stringent in most cases during the 14th and 15th centuries. A parallel development occurred during the same period, in the position of the urban poor, after the inquisition during the 13th century had already eliminated many critical and rebellious elements. ${ }^{4}$ Demands for serious social change could almost always be made to look like heresy; and although there were a few later reform movements in some cities, the secular city oligarchies retained the backing of the Church, and for the mass of the poorer people the rule was obedience to their ecclesiastic and secular superiors.

The ruthless pursuit of the economic and status interests of the elite of each city exacted several kinds of long-run costs. Interests can be pursued ruthlessly only if they are known, or seem to be known, that is, if they are short-run interests, or if their pursuants have a very arrogant confidence in their ability to foresee their interests in the long run. Italian city leaders would betray a rival or an ally as ruthlessly as the Venetians would cut down a tree in the Italian or Dalmatian mountains. The latter practice led to soil

1 Cf. L. Salvatorelli, L'Italia comunale (Milan, Mondadori, 1940), p. 315. W. F. Butler, The Lombard Communes (New York, Scribners, 1960), pp. 80-91.

2 Salvatorelli, op. cit., pp. 436-438.

3 G. Salvemini, "Un comune rurale nel secolo XIII", Studi storici (Firenze, Tipografia Galileiana, 1901), pp. 20-26; Cf. also Luigi Salvatorelli, op. cit., p. 174.

4 Cf. Salvatorelli, op. cit., pp. 460-464. 
erosion, the former to the erosion of political trust, both within and between communities. The ability to make and keep alliances is closely related to the ability to win, retain and merit trust, to make compromises and to keep them, to be mindful of the interests of others, and mindful of the uncertainty of human foresight, of the need for moderation, and of the need to reassure one's partners they could rely on getting some of the benefits of the doubt under the uncertain contingencies of the future. All these are habits of mind and behavior which are acquired and practiced most often in domestic politics.

By losing these habits of cooperation, compromise and trust at home, the elites of each Italian city-state also lost them in their dealings with all other cities. From an early stage most of the Italian cities lost the ability to make lasting alliances with one another. War between cities - whose rivalry of territorial expansion compounded their rivalries of trade - became the rule of North Italian politics; and the chessboard pattern of city alliances, already described earlier, testified to the prevailing hostility of neighbor against neighbor.

The most serious long-run cost of this arrangement was the loss of civic integration. The poor continued to obey, but they ceased to care. They lost interest in who was to rule their city - which family or faction, which mercenary leader, or which outside conqueror. This effective withdrawal of the mass of the people from politics and military matters destroyed the basis of constitutional government. In domestic affairs, it left each city the prey of bloody feuds of elite families and factions, ending usually in the tyranny of some newly emerging prince, or exceptionally in a tight oligarchy of a few families, as in Venice. Against the outside world, the same popular withdrawal of support - even more than the disunity of cities and factions deplored by Machiavelli - eventually made each city and all of Italy defenceless. Between 1494 and 1525, all of Lombardy — and much of the rest of Italy - was fought over as a piece of booty by foreign armies, many of which numbered fewer soldiers than there were men capable of bearing arms in the Lombard cities and villages. ${ }^{5}$

\section{ANTAGONISTIC COOPERATION: THE STRATEGIES OF THE GERMAN CITIES}

Many of the German cities, like many other cities in Northern Europe, had grown up from settlements of long-distance traders, with no tradition of, or

5 The French army at Novara in 1512 was estimated at 22,000 men, at Marignano in 1515 at 30,000 . The total French force under Francis I in North Italy - "unprecedented in Italy" - was reported at 75,000 , including numerous garrisons. Nabholz, et al., Geschichte der Schweiz (Zurich, 1432-38), I, p. 304-307. The population of Lombardy was well in excess of half-a-million, and the number of men capable of bearing arms - which in Schwyz and Uri amounted to one-quarter of the population - was in Lombardy alone well above 100,000 . 
interest in, territorial government; and eventually most German cities left the government of the countryside - and thus of more than four-fifths of the German people - to the rural nobles outside their walls. In contrast to their counterparts in Italy and Southern France, the German nobles as a rule did not reside in cities. Most German and Flemish cities made no sustained efforts to include the rural nobles in their citizenship. Where they did try to bestow the status of Ausbuirger or Pfahlbürger upon minor rural nobles or well-to-do peasants, such attempts were generally discouraged by the greater nobles, by the territorial princes, both clerical and secular, and by the Emperor himself. Cologne and some other Rhenish cities in the 13th century concluded treaties which made some rural nobles into "noble citizens" who did not have to reside in town but were obligated to give military assistance against pay. "The Rhenish cities do not even think, however, of conducting a policy of territorial expansion with the aid of these treaties." ${ }^{\circ}$ Imperial prohibitions of, or statements of opposition to, the voluntary or forcible incorporation of rural nobles as the citizens of cities are on record by Frederick I in 1182 against the city of Trento, by Frederick II in the 13th century, by Charles IV in the Golden Bull of 1356, and most revealingly, in a sworn treaty of 1368 between the Swabian nobles and cities, in which the cities of Freiburg-im-Breisgau, Breisach and Neuenburg were prohibited from accepting anyone as Ausbürger in the future - so that here the Swabian cities themselves become sworn guarantors of the prohibition. ${ }^{7}$ Freiburgim-Breisgau, the first city founded explicitly on the Italian model by the Zähringer dynasty, in 1120 - as were later Bern and Fribourg - thus did attempt to carry on an Italian-style policy of the incorporation of nobles and of territorial expansion, but was stopped by the joint resistance not only of territorial princes and nobles, but in the end also by that of the other Swabian cities.

The German Imperial and Hanseatic cities thus followed a mixed strategy of types 1 and 4 . They pursued their trade and craft monopolies against the countryside, but left the peasants to the rule and exploitation of the nobles; and these nobles, rather than the peasants, were the chief customers for many city products and services. Despite the recurrent conflicts between cities and nobles, the German cities were thus not mainly the opponents of feudalism, as liberal-democratic and Marxist writers in the 19th and 20th centuries have pictured them, but rather the elites of these cities were more often themselves a privileged estate, the tacit collaborationists of aristocratic rule in the countryside, enemies of rural handicrafts, and co-exploiters of the peasantry. Pirenne's characterization applies no less to the treatment of the peasants by

- Edith Ennen, Frühgeschichte der europäischen Stadt (Bonn, 1953), p. 256, and generally pp. 250-257.

7 Cf. Ennen, op. cit., p. 257; H. Planitz, Die Deutsche Stadt im Mittelalter (Cologne, 1954), p. 274. 
the cities of Flanders and Germany than it does to the latter stages of their treatment by the city of Florence:

The peasants who dwelt about them did not seem to be compatriots at all. The one thought was to exploit them profitably. With all their might they stood on guard to prevent the peasants from freeing themselves from the industrial system of which the cities had a monopoly. The task of provisioning the cities was likewise imposed upon the peasants ...8

The majority of German cities, however, did not have Imperial status and the far-reaching self-government - and often virtual sovereignty - which this implied. Rather they remained under the rule of their ecclesiastic or secular overlords, or became part of the expanding possessions of some territorial prince. In these cases, as in Flanders and in much of France, the city elites followed on the whole strategies of types 5 and $6-$ collaboration with the Church and with the territorial prince - in pursuit of their interests against the peasantry, the lesser rural nobles, and against the poorer strata within the urban community itself. Narrowing city oligarchies thus collaborated with growing princely absolutism, from the 14th and 15th centuries onward, culminating in the increasingly absolutist states of the 16th and 17th centuries - slighting or sacrificing in the pursuit of stable privilege gradually not only their interests in civic integration but also in external and even internal self-government.

These developments, to be sure, did not all occur at once. The development of the German and Flemish cities was characterized at all times also by a strong element of cooperation, going back, in many cases, to the brotherhoods or gilds of long-distance traders which had a role in the rise of many of these cities. Another cooperative element was the gilds of artisans, which played a larger and longer-lasting role in many German cities than they did in Italy or Flanders - where their strength was soon undermined by the growing cleavages between large and small craftsmen and entrepreneurs, between masters and perpetual journeymen, and eventually between capital and labor. In the German cities these antagonistic developments were retarded or moderated, and the institutions, attitudes and social practices of the gilds and of economic cooperation persisted for a longer time.

Perhaps as a result, there persisted in many German cities also a somewhat moderate and cooperative style of politics. The typical artisan's gild aimed at securing a livelihood for all its members; within its ranks, no one was to

8 Henri Pirenne, Medieval Cities: Their Origins and the Revival of Trade (Princeton, Princeton University Press, 1946), p. 211, and generally pp. 211-215; cf. also p. 215, for the indirect pressure on the peasants to produce more, which resulted from these city policies. For the hostility of the German cities against rural handicrafts, Cf. Luitge, op. cit., p. 164; for the hostility of Bruges, Ypres and Ghent against smaller cities and for the destruction of looms outside the city walls by the weavers of Ghent, see J. C. Gemperle, Belgische und schweizerische Städteverfassungsgeschichte im Mittelalter (Louvain, Bibliothèque de l'Université, 1942), p. 321, with references. 
be eliminated ruthlessly by competition, but some compromise solution was to be found, acceptable to all members. In such practices as the fixing of measures and of standards of quality, as well as of prices, and sometimes in the joint purchase of materials, the craft gilds resembled certain aspects of modern producers' cooperatives and stressed common interests of their members which were not necessarily or always directed against a third party. In relation to other gilds, each gild sought a high price for its products and a low price for those products of other gilds - such as bread from the bakers - which its own members had to buy. Since it was obvious, however, that no gild could dictate to all others - nor get along without their services - the manifest facts of economic interdependence once more favored policies of compromise and mutual cooperation.

A similar style of greater cooperation and readiness to compromise characterized the relations of many German cities toward one another. There are no cases of long-sustained and devastating hatred between German cities, such as was notorious between Venice and Genoa, nor was there usually much readiness on the part of a major city to ally itself with the foreign enemies of another city, as in the alliance of Bruges with the pro-English and of Ghent with the pro-French faction in Flanders in 1338-39.9 The German cities, by contrast, showed remarkable ability to form alliances and to keep them for a long time. The Rhenish and the Swabian cities, respectively, formed several such alliances in the 13th and 14th centuries, which culminated in 1381 in the great alliance of the Rhenish and Swabian Leagues of Cities, which then was defeated by the South German nobles in 1388. That defeat ended the independent political role of the South German and Rhenish cities and opened the way for the rule of territorial princes, just as in the same decade the defeat at Roosebeke in 1382 had ended the political role of the cities of Flanders, and opened the way for the later establishment of the Burgundian state. ${ }^{10}$ In North Germany, however, the Hanseatic League of cities reached the peak of its power about 1370 and persisted in strength until the late 15 th century, to peter out in the 17 th century, maintaining a shadow-like existence with Kontors, i.e., offices, in London until 1852 and Augsburg until 1863.11

- Gemperle, op. cit., p. 313 . The Flemish developments in the 14 th century resembled some of the features of the ruthlessly competitive politics of Northern Italy. The collapse of the autonomy of the Flemish cities and their disastrous defeat at Roosebeke in 1382 have been ascribed to three major factors: the bitter social and industrial conflicts within the cities, the complete passivity of the rural population, and the resentment of the lesser towns at their exploitation by the three dominant cities of Ypres, Ghent and Bruges. Gemperle, op. cit., p. 317.

10 See preceding note.

11 For a summary sketch, see Paul Cram, "The Hanseatic League", in W. L. Langer, Encyclopedia of World History, revised ed. (Boston, Houghton Mifflin, 1960), pp. 307310. Cf. also D. Schäfer, Die deutsche Hanse (Leipzig, Velhagen and Klasing, 1903); Konrad Mass, Die deutsche Hanse (Jena, Diederichs, 1926); Karl Pagel, Die Hanse (Oldenburg, Stalling, 1942); J. A. Gade, The Hanseatic Control of Norwegian Commerce 
The ability to maintain stable alliances in protection of their own autonomy and interests was one of the most interesting features of the German cities in general, and of the Hanseatic cities in particular. The very looseness of the Hanseatic League - its lack of majority rule, or of any common offices of government over its members, its limitation to specific common economic interests, and sizable rewards which the common pursuit of these interests ensured - all these may have contributed to its long survival.

Yet the Hanseatic League was not free from the characteristic limitations which the pursuit of the mixed strategies of types 1, 4 and eventually 6 entailed. A bare summary tells the tale:

The objectives of the league were mutual security, extortion of trading privileges, and maintenance of trade monopoly wherever possible... In the 15th century the league was... weakened by the struggle within the member towns between the democratic guildsmen and the patrician oligarchy. The league threatened the expulsion of "democratic" towns. The German princes... gradually reduced the freedom of various powerful members of the league...12

The ability of the German cities to maintain alliances, and often also a measure of civic solidarity, perhaps came from the same cause that was also the root of their ultimate political weakness. These cities were only partial states, and they showed no serious intention of becoming full-fledged ones with their own substantial territories in the manner of the Italian city-states. They thus could only supplement the feudal and aristocratic social system, and the princely territorial states into which that system eventually consolidated, but could offer no effective alternatives to these developments.

Many German cities never attained Imperial status but remained under the role of their bishops or secular overlords, sometimes in fairly complete dependence but more often with some limited degree of internal self-government. Even where such cities strove, however, to enlarge their autonomy such as Cologne which temporarily freed itself from the control of its bishop and became a prominent member of the Hanseatic League - they, too, eventually fell under internal oligarchy and external dependence, in accordance with the basic limitations of the political strategies which the mass of German cities had adopted. This was particularly true of the cities of Austria and the Tyrol, as well as of many Bavarian cities which, in general, pursued their interests in alliance with, and increasingly in obedience to, the territorial rulers. Since these rulers also were increasingly backed by the Church, both Austria and Bavaria became marked strongholds of centralized princely power.

during the Late Middle Ages (Leiden, Brill, 1951); G. Heitz, ed., Hansische Studien (Berlin, Akademie-Verlag, 1961).

12 Paul Cram, in Langer, op. cit., pp. 309-310. 


\section{COLLABORATION WITH THE MONARCH: THE PATTERN OF THE COMMUNES IN FRANCE AND SAVOY}

A similar outcome was reached by a somewhat different pathway by the communal movement and the cities of France. These cities followed mainly strategies of the type 6 of our Table. Like the German cities, they left the countryside and the peasant mass of the French people to the rule of nobles. In Southern France, some nobles took up residence in towns, but in most of France, the small nobility remained rural. Like the German cities, the French cities pursued policies of economic monopoly against the countryside. Within the cities, the citizens were united by oaths, there was urban self-government, there were often gilds, and in the early stages there was a measure of civic solidarity. As in Italy and Flanders, however, there soon developed considerable cleavages between rich and poor. Already in the 13th century, the trend in most French cities was toward oligarchy and plutocracy, usually in conjunction with a policy of alliance with the French kings. Such monarchs as Philip II Augustus (1180-1223), Louis IX (St. Louis, 1226-1270) and Philip IV (the Fair, 1285-1314) protected the towns against the nobles, and increasingly the oligarchies within the towns against the lower orders, but they also drew upon the towns, first as sources of military support - such as Philip II in the victorious battle of Bouvines against England, Emperor Otto IV, and most of the feudality of Flanders, Brabant and Lorraine and later they drew even more heavily upon the cities, and particularly upon the communes, as sources of taxation. In 1262 Louis IX introduced an annual royal audit of communal finances. The cities were powerless to resist the royal exactions; after 1270 the communal movement declined; the city of Noyon went bankrupt in 1291; and the inhabitants of a number of cities petitioned the monarch to abolish their communal form of government which had become an instrument of local oligarchy and ever-heavier royal taxation. By the 14th century, the communal era in France was ending - until under Louis XI in the 15 th century the rule of city oligarchies was finally consolidated and the notion of autonomous communes fell into desuetude. ${ }^{13}$

In Savoy, communal charters of liberties were granted to the larger market towns by the princes of the dynasty of Savoy or by their major vassals. This happened later than in France. During the 13th century, twenty towns in Savoy were granted such charters, beginning with Yenne in 1215; during the 14th century, such grants multiplied. These communal charters obliged each

13 Cf. Charles Petit-Dutaillis, Les communes françaises: caractère et évolution des origines au XVIIle siècle (Paris, Albin Michel, 1947), pp. 81-83, 102-108, 126, 149, 174-184, 220, 235-244, 363. Cf. also Cram in Langer, op. cit., pp. 229-232. An exceptional course was taken in the 13th century under English protection by Bordeaux which acted like a republic in concluding alliances with rural nobles as well as with the leaders (prud'hommes) of near-by villages. These developments did not lead, however, to a territorial state. In the course of the 14th century Bordeaux became an oligarchic city under the rule of the French monarchs. Ibid, pp. 158-161. 
town to furnish taxes and a stated number of men for limited military service; and they provided for personal freedom of town residents, for trading rights and privileges, for town assemblies and syndics, and for limited judicial autonomy, particularly in regard to market regulation. The communes of Savoy were thus far less political in nature than the French communes had been in their time of flowering. Their liberties had not been established in response to the political demands, pressures and struggles of their citizens, but rather they had been granted peacefully, most often by Counts of Savoy who were looking for political and financial counterweights to the power of their nobles. ${ }^{14}$ On that innocuous level, many of these charters persisted into the 18th century, without interfering with the gradual establishment of an absolutist state.

\section{THE FULL-FLEDGED CITY-STATES OF SWITZERLAND: POLICIES OF INDEPENDENCE AND ALLIANCE}

Many of the details of the history and practices of the major cities that eventually became Swiss - such as Lucerne, Zurich, Bern, Fribourg, Solothurn, Basel, Schaffhausen, St. Gallen and Geneva - resemble those of the European cities that we have surveyed. What is different are the sums of these details - the patterns of policy to which they add up.

By and large, the Swiss cities followed strategies of the types 3 and 2, as shown in our Table, and they followed strategies of type 1 in pursuit of the interests of their elites only subject to the extent that this proved compatible with these overriding strategies. The Swiss cities thus aimed at the status of full-fledged territorial states on the model of the Italian communes - so much so that at least one historian has described the formation of the "Swiss and South German" city-states as extensions of the Italian communal movement. ${ }^{15}$ At the same time, however, their internal and external policies were more cooperative and less competitive, more moderate and inclined to relatively stable alliances and compromises; and in all these respects they resembled the traits of German rather than Italian cities. Like the French communes, they liked to align themselves in the 13th century with distant monarchs against nearby nobles, but unlike the French towns, they kept and thereafter steadily increased their fiscal and political autonomy to the point of practical independence. In this they once again resembled the Italian communes, and so they did in their steady drive to acquire territories and 14 Paul Guichonnet, Histoire de Savoie, 2nd ed., pp. 66-67. For many details of the development of Swiss Cities and States, see Hektor Amman and Karl Schib, Historischer Atlas der Schweiz (Aaru, Sauerlander, 1951), passim. The many writings of Hektor Amman should be considered, especially "Das schweizerische Städtewesen des Mittelalters", Extrait des Recueils de la Société Jean Bodin, Tome VII, 2e partie (Bruxelles, 1956).

15 Ennen, op. cit., p. 257. 
citizens outside their city walls, and to become virtually complete states.

In all these respects, their political strategies look like mixtures of those of their neighbors to the North and South. In the most important respects, however, their strategies were unique. Their attitude towards the peasants on the whole was one of alliance rather than of exploitation. The peasants of many rural communities received urban citizenship, as the peasants of the Hasli Valley, of Saanen, Chateau d'Oex, and other communities of the Berner Oberland did in Bern. Elsewhere, leading peasants became urban citizens. Even where peasants became subjects of a Swiss city, their rights and autonomous institutions ordinarily were confirmed, and their position tended to improve until the 16 th century. Above all, the peasants remained armed; the cities continued to depend on them for an important part of their military manpower; and the peasants fought well, side by side with the town burghers.

In regard to economic policy, the cities did not destroy the rural handicrafts, nor did they push their monopolistic or gild interests too far at the expense of the peasants. "The urban craft gilds never succeeded, except for luxury trades, to concentrate industrial and craft production monopolistically in the towns." ${ }^{10}$ This state of affairs persisted into modern times. Data for Zurich for 1770 show a proportion of 4.5 per cent craftsmen among the rural population of the Canton, as against 8 per cent craftsmen in the city itself. ${ }^{17}$

Other trade and tax policies toward the peasantry were similarly moderate. The large houses of the prosperous peasants on Lake Zurich, in the Emmenthal, the Berner Oberland and elsewhere were commented upon by astonished foreign travelers as late as the 17th and 18th centuries. Credit and the need to repay debts with interest were instruments for the dispossession of minor nobles rather than of peasants.

As a result of these policies, no large number of dispossessed peasants was available as a source of cheap wage labor and of any large urban proletariat. Together with the persistence of rural handicrafts, these conditions retarded the numerical growth of the Swiss cities. If we consider each city without its surrounding countryside, Zurich and Bern counted from the 14th through the 16th century only 6,000 and 5,000 inhabitants, respectively, against estimated populations of 20,000 for Nurnberg, and over 50,000 for the chief cities of Flanders and Italy. Only by counting the rural population of each city canton do we get perhaps 35,000 for Zurich and 80,000 for Bern figures that reflect more nearly the effective size and power of these communities. ${ }^{18}$

10 Emil Walter, Soziale Grundlagen der Entwicklung der Naturwissenschaften in der alten Schweiz (Bern, Francke, 1958), p. 34.

17 Walter, op. cit., p. 35, with references.

18 Cf. Bickel, Bevölkerungsgeschichte und Bevölkerungspolitik der Schweiz (Zurich, Gutenberg, 1926), pp. 49, 62-63; Gemperle, op. cit., pp. 256-257, with references. 
In this manner, the elites of the Swiss cities had to sacrifice, or at least to play down, their potential interests in craft monopolies, and in trade and tax monopolies against the peasantry, as well as a significant part of their interests as potential employers or creditors against the rural and urban poor. By the same token, they could not pursue very far the symbolic expressions of this range of interests hostile to the peasants and the urban poor. They could not press effectively their claim to a superior status of all townsmen against peasants, nor could the rich elevate themselves so far above the poor within each city as was commonplace in Italy and Flanders.

In exchange for not pressing strongly those of their potential interests that would have brought them into protracted conflict with the peasants and the urban poor, the Swiss city elites made considerable gains in regard to other interests. Their trade routes were always open, and property was safe. An unprotected man could carry gold in his hand all across Switzerland without coming to any harm, wrote the chronicler Niklaus Schradin in the 15th century..$^{19}$ Though mountains offer potential shelter to robbers, and mountain populations often have aided them, this was not the case on the Gotthard route, although there were occasional complaints in the Grisons. Improved security could also be attained in matters of credit, since each Canton bound itself to give fair protection through its own judges to the claims of Confederates.

Thanks to the military backing of their own peasants, and to the alliance with the Alpine Cantons, the leading burghers of the city Cantons could make substantial gains in their claims to social equality with the rural nobles. Although the niceties of etiquette would vary from the 14 th to the 16th century with time and place and power, the difference between the mounting confidence of the burghers of Swiss cities and the declining prestige of their counterparts in France, Savoy, and in Germany - including notably Bavaria and Austria - was conspicuous.

Even more conspicuous were the gains of the Swiss cities in regard to internal freedom and self-government, to independence, to civic integration, and to the civic and military participation of a large proportion of their people. In all these respects, the Swiss cities did much better, and for a far longer time, than did almost all other cities in Europe.

The choice of interests to be put foremost in the pursuit of policy is in part also the result of the potential allies and alliances that are available for their support. Once chosen and maintained for a longer time, however, each alliance and its outcomes in turn will strengthen or weaken the original interests for which it was invoked, and thus remake - reinforce or modify the earlier interest configuration that gave it birth. In the case of the Swiss cities, their most important potential allies turned out to be the Alpine Cantons. Nowhere else in Europe were there such unusual peasants with such skills 19 Wolfgang von Wartburg, Geschichte der Schweiz, p. 79. 
and experiences in transport, trade, monetary and military matters, with such effective political organizations, and located astride such crucial trade routes and passes.

Once they had been picked for allies, however, the presence of these irreversibly self-governing Alpine peasants and their communities inevitably influenced the political and social climate in the rural environment of such cities as Lucerne and Zug, Zurich and Bern, and eventually all the way to Fribourg, Basel, Schaffhausen and St. Gallen. Even within the cities themselves, wherever there were elements pressing for a more democratic communal order, the example and the potential support of the Alpine communities had its effect. Moreover, once a city had allied itself with the Alpine Cantons, these were apt to treat the alliance as "eternal" and in effect indissoluble; they would fight against any city that would later try to break away, and thus indirectly strengthen those elements within each city that would make the alliance permanent.

There is no room here to put these findings in the wider context of Swiss history and social evolution. One point, however, may be indicated here. Medieval Switzerland was not a country defined by nature or long-established history, within whose fixed borders certain policies, strategies, institutions, habit patterns and social and political culture were then adopted. Rather, certain political strategies were chosen, opportunities taken and mutual commitments made; and the collection of the rural and urban communities where such mutually compatible strategies were chosen and where such commitments became stabilized then came to form the confederation and finally the country that is now known as Switzerland. The particular institution of the Swiss city Canton - like that of the Swiss rural Canton - was made by the invention and adoption of particular strategies and the particular social order to which these strategies led; and the persistence and consolidation of these cantons then gradually made the people that calls itself "Confederates" and the nation we call Swiss.

\author{
KaRL W. Deutsch \\ Yale University \\ and
}

HeRManN WeIlenManN

Volkshochschule des Kantons Zürich and

Yale University 